\title{
The Effect of Multimedia Training Program on Anxiety in Patients Admitted to Chemotherapy Departments
}

\author{
Gholamizadeh. M 1 \\ *Habibi. $\mathrm{H}^{2}$ \\ Kalroozi. F3 \\ 1- MSc in Student of Psychiatric \\ Nursing, Faculty of Nursing, \\ Aja University of Medical \\ Sciences, Tehran, Iran. \\ 2- ( ${ }^{*}$ Corresponding Author) \\ MSc in Nursing, Instructor, \\ Faculty of Nursing, Aja \\ University of Medical Sciences, \\ Tehran, Iran. \\ Email: hengamehabibi@ymail.com \\ 3- MSc in Nursing, Instructor, \\ Faculty of Nursing, Aja \\ University of Medical Sciences, \\ Tehran, Iran.
}

\begin{abstract}
Introduction: Patients-with cancer in chemotherapy wards, face high degree of mental tensions such as anxiety in disease. These patients require effective training methods to manage anxiety. Multi-media education is one of the most useful and flexible educational strategies.
\end{abstract}

Objective: Thus, the present study aimed to investigate the impact of multimedia education program on the level of anxiety in patients admitted to chemotherapy wards.

Material and Methods: The present study is quasi-experimental and was performed on 30 patients with definite diagnosis of cancer referring to selected AJA hospitals in Tehran. Sampling was done randomly. The researcher gave educational CDs to the intervention group and no intervention was performed in the control group. The Spielberg's Anxiety Inventory contained 20 multiple choice questions. Finally, the data were analyzed using SPSS software 16.

Results: The results showed that there was no significant difference between the mean anxiety scores before and after the test group (before: $M=43.96 \pm 6.05$, after: $M=43.40 \pm 5.95$ ) and the control group (before: $M=45.13 \pm 10.06$, after: $M=$ $47.53 \pm 10.32)(\mathrm{P}>0.05)$.

Discussion and Conclusion: The results of the present study showed no significant difference between the mean anxiety scores before and after the test group, but it is recommended to perform further comprehensive studies.

Keywords: Anxiety, Cancer, Chemotherapy, Multimedia. 


\section{بررسى تأثير برنامه آموزشى هند رسانهاى بر اضطراب بيماران بسترى در بخشهاى

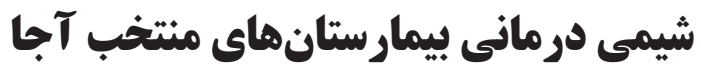

مهدى غلامىزاده'، "هنغامه حبيبى"، فاطمه كلروزى"

جكکبه

مقدمه: بيماران بسترى در بخشهاى شيمى درمانى، ميزان بالايى از تنشهاى روانى از جمله اضطراب در بيمارى را تجربه

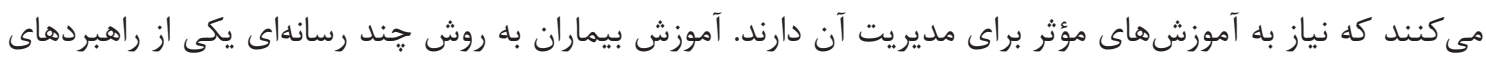
مفيد و انعطاف رِذير آموزشى است. هدف: مطالعه حاضر با هدف بررسى تأثير برنامه آموزشى جند رسانهاى بر اضطراب بيماران بسترى در بخشهاى شيمى درمانى صورت كرفت. مواد و روشها: مطالعه حاضر يك يزوهش نيمه تجربى مى بـاشد كه در مورد •ب بيمار با تشخيص قطعى سرطان كه به

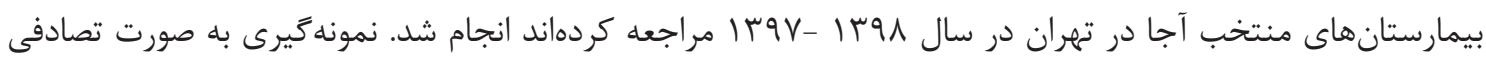

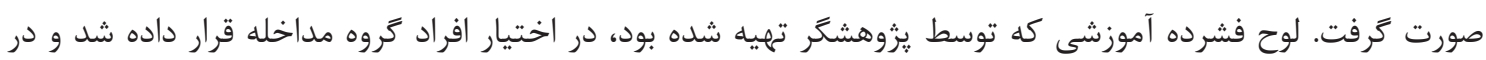

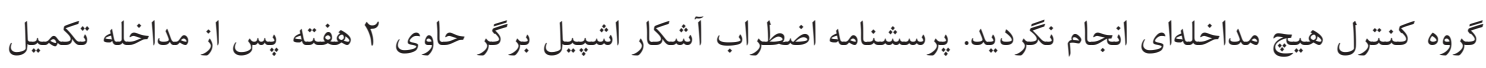

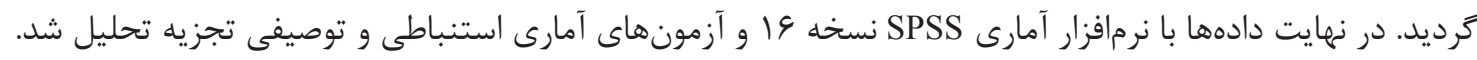

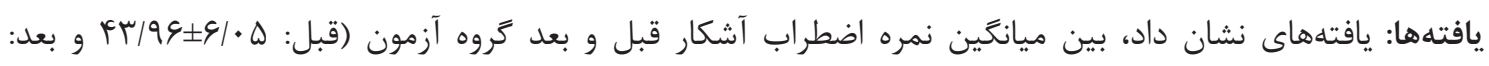

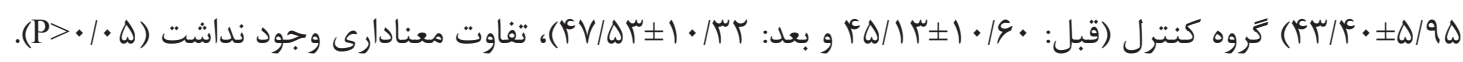
بحث و نتيجه

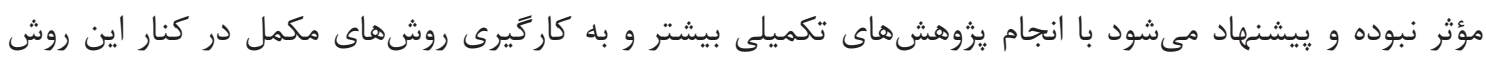
تأثيرات آنها بررسى كردد.

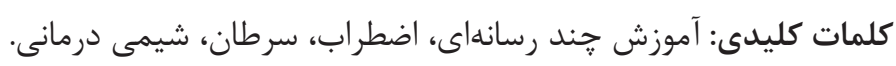

\begin{tabular}{|c|c|c|c|}
\hline $1 \mu q \Lambda / F / k$ & تاريخ دريافت: & 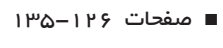 & 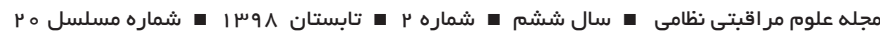 \\
\hline $\mid \mu q \wedge / k / 19$ & 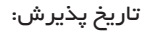 & & \\
\hline 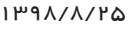 & 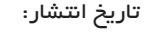 & & \\
\hline
\end{tabular}

بودهاند به عنوان مثال در كشور جين بر اساس مطالعهى انجام شده مقلمهـ

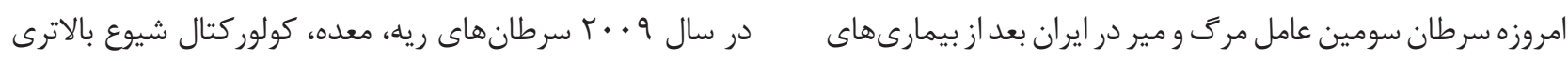

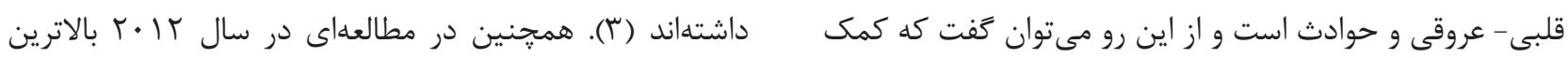

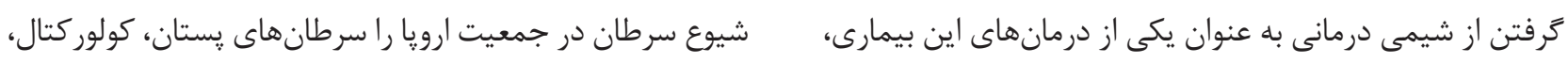

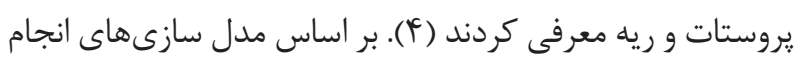

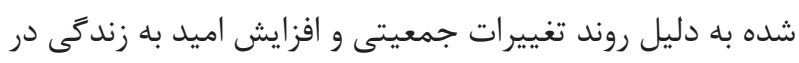

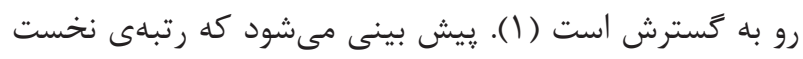

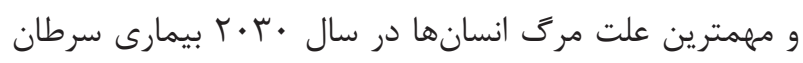

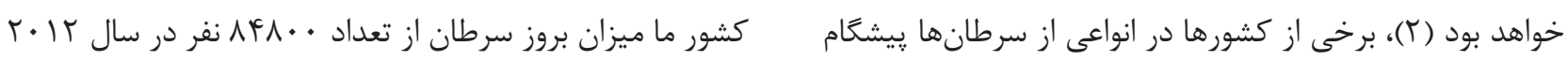


اجراى برنامههاى آموزشى براى اين دسته از بيماران است. امروزه

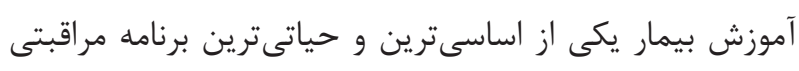

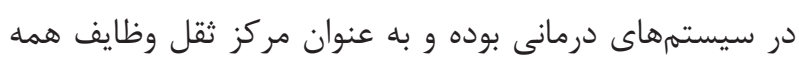

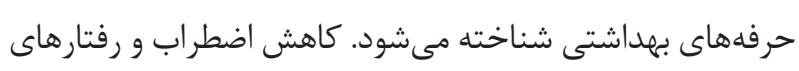

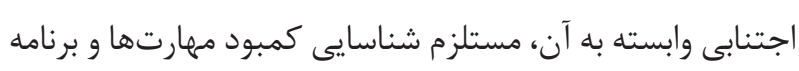

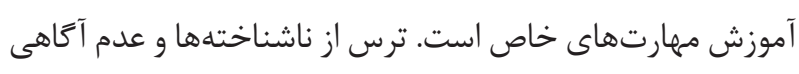

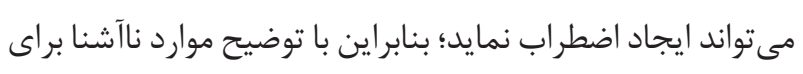

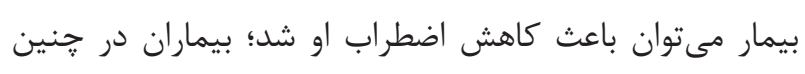

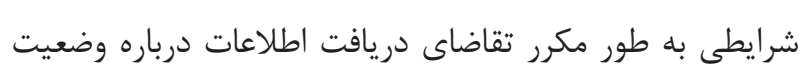

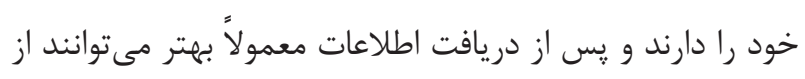

الكوى سازكًارى استفاده نمايند (• ().

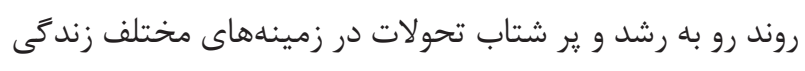

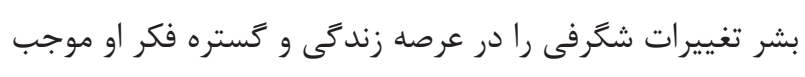
شده است. افزايش روزافزون استفاده از فناورى اطلاعات و ارتباطات تحولى عظيم را در تمام حوزهها و از همه مهمهر حوزه آموزش و و

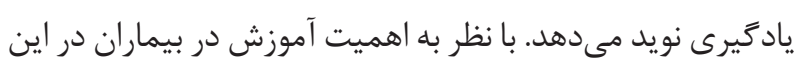

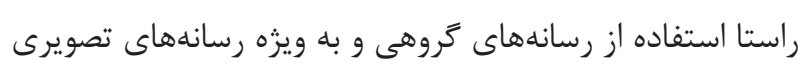
توسط بعضى از محققين و صاحب نظر ان به عنوان يكى از شيوههاى

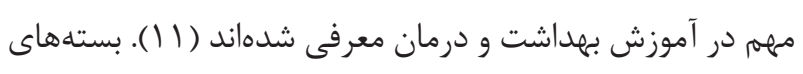

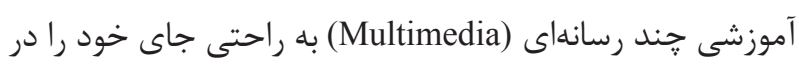

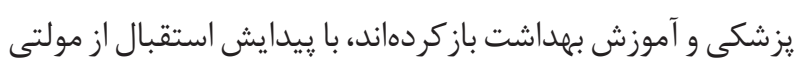

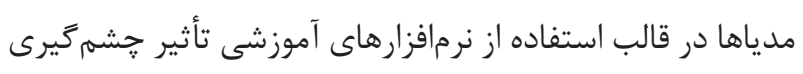

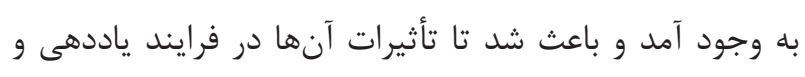
ياد يكى از بهترين روش هاى آموزشى است كه با ارائه حجم بالايى از

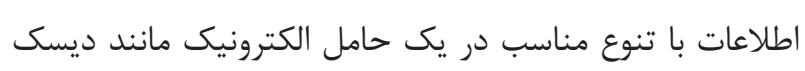

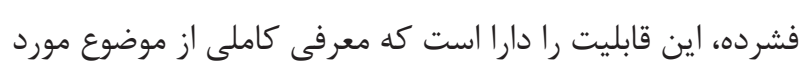

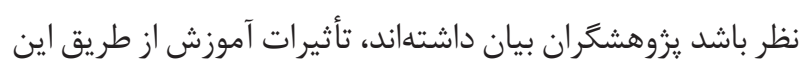
تكنولوزى از ساير موارد بيشتر مىباشد و به راحتى باعث تغيير

رفتار در مخاطبين مىشود (باس ). محورىترين نكته قابل بحث اين است كه بسته آموزشى جند

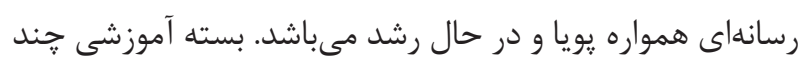
رسانهاى به علت كاربردهاى گستردهاى كه يِيدا كردهاند و ميزان تأثيرى كه روى مخاطب مى كذارند مورد توجه بسيار هستند.

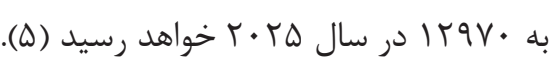

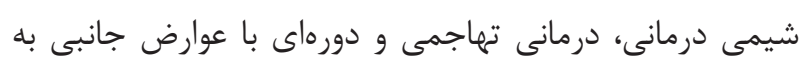

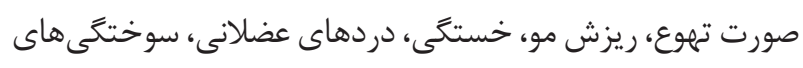

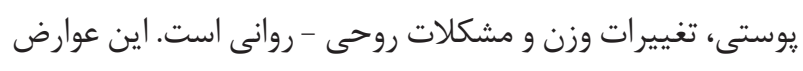

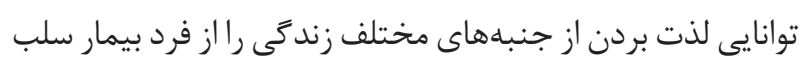
مى كند (9). اضطراب موجب افزايش مشكلات در درمان بيماران

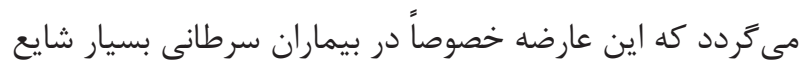

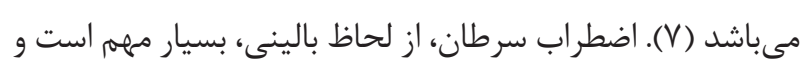

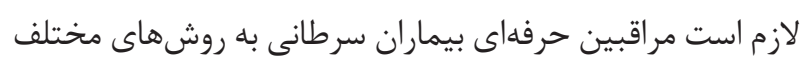

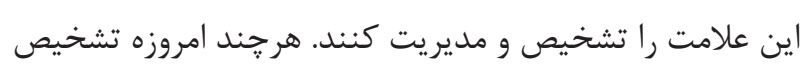

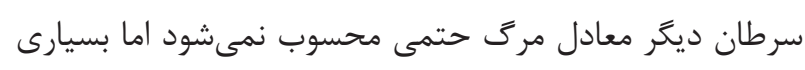
از مطالعات در كشورهاى غربى و برخى كشورهاى آسيايى نشان داده است كه جنين تشخيصى موجب بروز مشكلات هيجانى و و

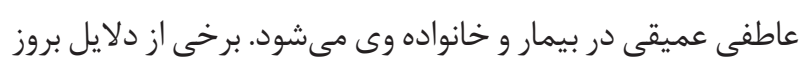
اين مشكلات، معانى ضمنى اين تشخيص در ذهن بيمار و خانواده

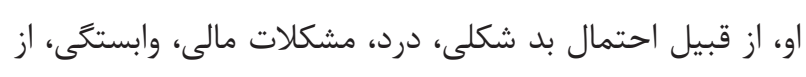

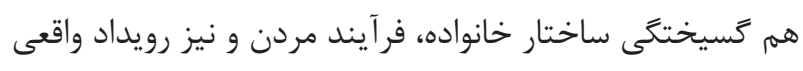
برخى از اين يديدها در زندگى بيماران است (9، (V).

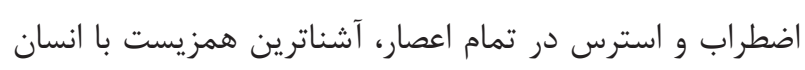

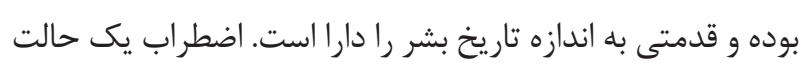

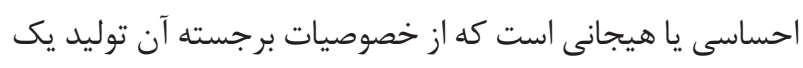

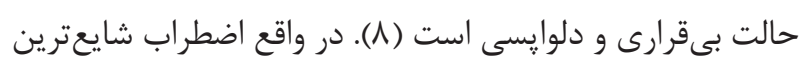
علامتى است كه در بيماران مبتلا به سرطان ديده مى شود. دامنه إنه

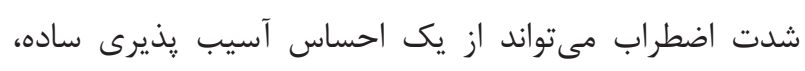
ناراحتى و ترس شروع شده و به يك احساس مخرب به صورت

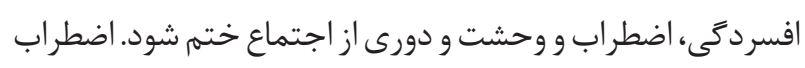

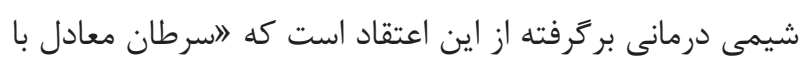

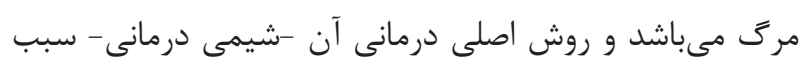

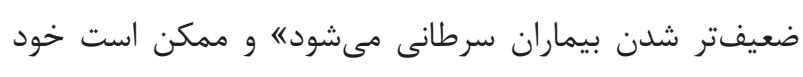

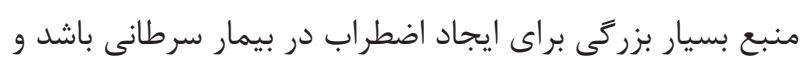

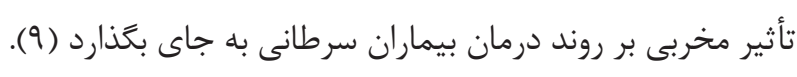
روشهايى كه جهت كاهش اضطراب بيماران مورد استفاده قرار

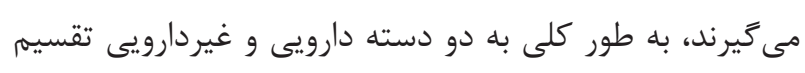

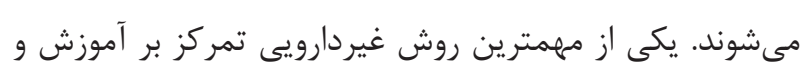


و وجود خلأ در اين زمينه، يزوهشكر بر آن شد تا مطالعهاى با

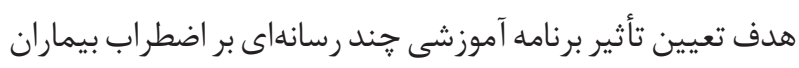
بسترى در بخشهاى شيمى درمانى طراحى اجرا نمايد.

\section{مواد و روشها}

مطالعه حاضر يك مطالعه نيمه تجربى است. جامعه مورد مطالعه

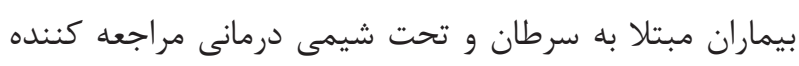

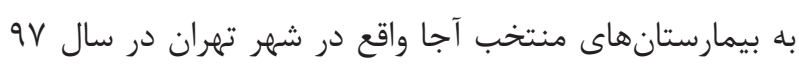

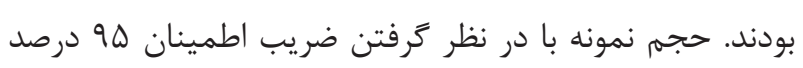

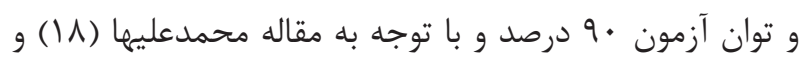

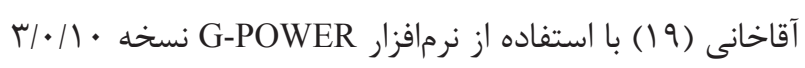

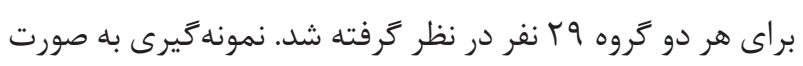

$$
\text { زير در دسترس بود. - مترك }
$$

\begin{tabular}{|c|c|c|}
\hline \multicolumn{3}{|c|}{$\begin{array}{l}\text { t Tests - Means: Difference between two independent } \\
\text { means (two groups) }\end{array}$} \\
\hline Analysis: & \multicolumn{2}{|c|}{ A priori: Compute required sample size } \\
\hline \multirow[t]{5}{*}{ Input: } & Tail (s) & $=$ Two \\
\hline & Effect size d & $=\cdot / \Lambda V V \cdot \Delta \Lambda$. \\
\hline & $\alpha$ err prob & $=.1 . \mathrm{\Delta}$ \\
\hline & Power (1- $\beta$ err prob) & $=. / 9$. \\
\hline & Allocation ratio N2/N1 & $=1$ \\
\hline \multirow[t]{7}{*}{ Output: } & Noncentrality parameter $\delta$ & $=r / r r q V r V k$ \\
\hline & Critical t & $=Y / . \cdot r T F \cdot V$ \\
\hline & Df & $=\Delta \varphi$ \\
\hline & Sample size group 1 & $=r q$ \\
\hline & Sample size group 2 & $=r q$ \\
\hline & Total sample size & $=\Delta \Lambda$ \\
\hline & Actual power & $=. / 9.9911 \%$ \\
\hline
\end{tabular}

روش كار بدين صورت بود كه ابتدا يزوهشكر پِ از كسب مجوز

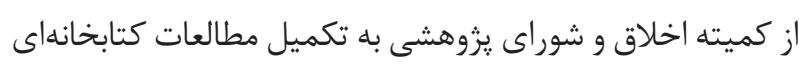

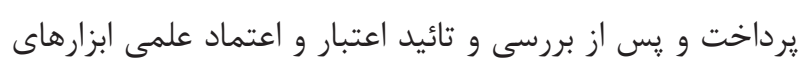

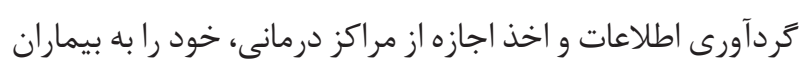

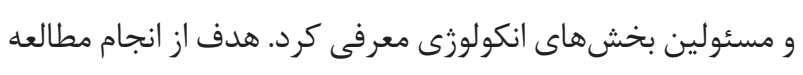

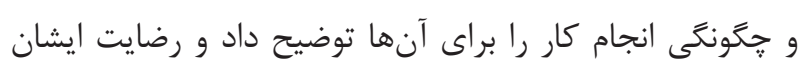
را جهت شركت در مطالعه جلب و به صورت كتبى دريافت كرد. بيماران داراى معيار هاى ورود در روزهاى زوج در هر دو بيمارستان
به عقيده يُوهشخران، بسته آموزشى جند رسانهاى مانند ساير

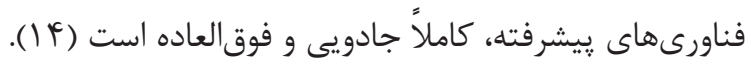
نتايج مطالعه كاسازو (Casazzo) و همكاران نيز نشان داد كه استفاده از CD درافزايش سطح اطلاعات، فعاليت اجتماعى، فعاليت فيزيكى كاهش مصرف وعدههاى غذايى نوجوانان ايالات متحده مفيد مىباشد (سا). در مقابل مطالعه محمدى و همكاران كه

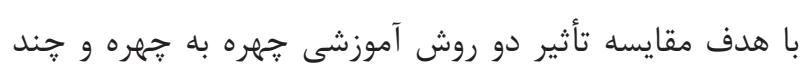
رسانهاى بر تبعيت از رزيم غذايى در بين بيماران هـ از إز سكته

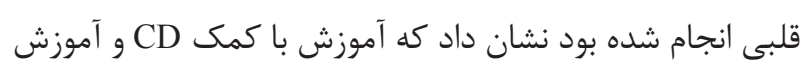
جهره به جهره هر دو به يك ميزان بر ارتقاء تبعيت از رزيم غذايى

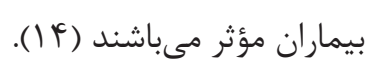
نتايج مطالعه ورعى و همكاران كه با هدف تعيين تأثير برنامه ֶند رسانهاى آموزش بر دانش، نكرش و عملكرد يرستاران در زمينه تزريق ايمن انجام شده بود نشان داد كه بين دانش، نكرش

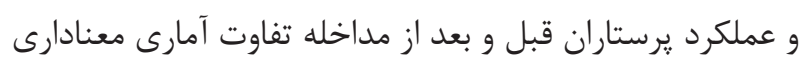
وجود داشت (ه (1). نتايج مطالعه كامب بل (Campbell) و همكاران نيز نشان داد افرادى كه با كمك ديسك فشرده آموزش ديده بودند

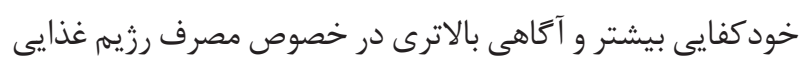
كم جرب نسبت به گروه كنترل داشتند (ع) (1). يافتههاى مطالعه صفارى و همكاران نيز كه با هدف مقايسه تأثير آموزش رزيم غذايى به دو روش سخنرانى و نمايش فيلم بر آكاهى و نخرش

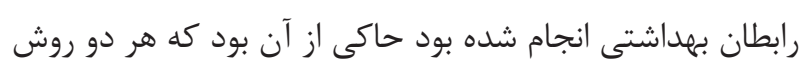

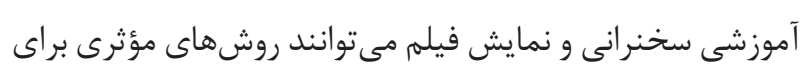

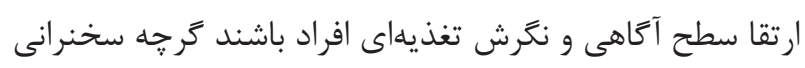
اثر بخشى بيشترى داشت (V) V Veulerse) در مطالعه كيولرز همكاران كه در بين بيماران دجار سندرم تونل كاريال Carpal) Tunnel Syndrome) داد سطح دانش افرادى كه به وسيله نرمافزار رايانهاى آموزش ديده

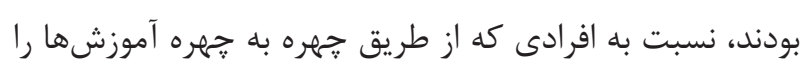
دريافت كرده بودند بالاتر بود اما از نظر سطح رضايتمندى هر دو كروه يكسان بودند (T) (I). با توجه به مطالب بيان شده و همرجنين دست نيافتن يزوهشگر به

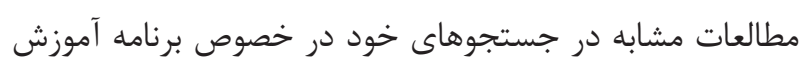
جند رسانهاى بر ميزان اضطراب بيماران مبتلا به سرطان در كشور 
مورد تائيد قرار كرفته بود و با استفاده از روشهاى آلفاى كرونباخ ضريب اعتبار بو • كزارش شده بود (ه) (Cronbach>s Alpha)

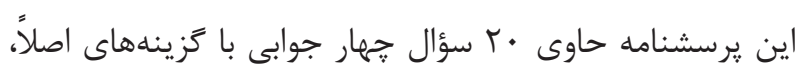

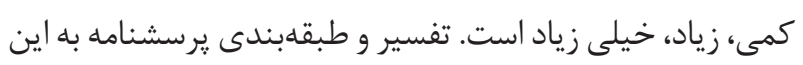

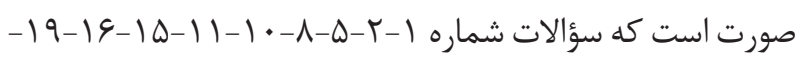

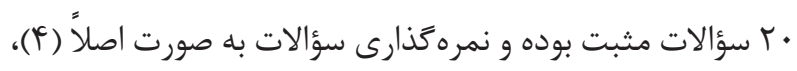

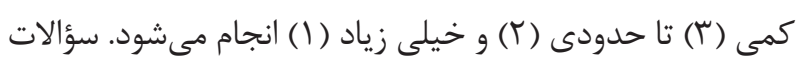
منفى كه شامل سؤالات شماره ب-Y

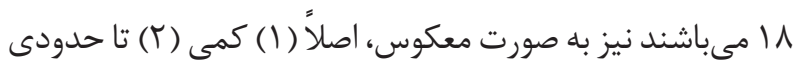

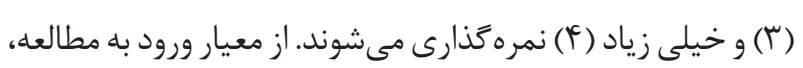

در گروه آزمون و بيماران در روزهاى فرد در هر دو بيمارستان در كروه كنترل قرار كرفتند. براى كردآورى دادهها در ابتداى كار يرسشنامه اطلاعات زمينهاى كرئد

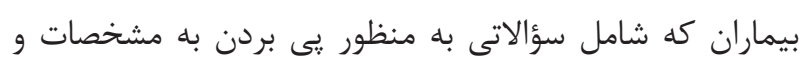
ويزگى هاى دموكرافيك (سن، جنس، سطح تحصيلات، شغل،

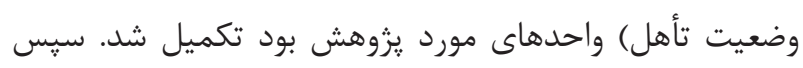

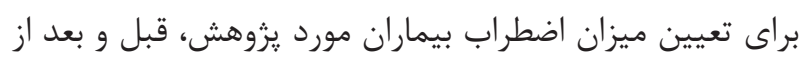

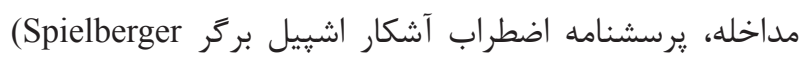
State- Trait Anxiety Inventory) روايى و پايايى اين يرسشنامه قبلاًد ايران توسط ورعى و همكاران

\section{ثبت نام}
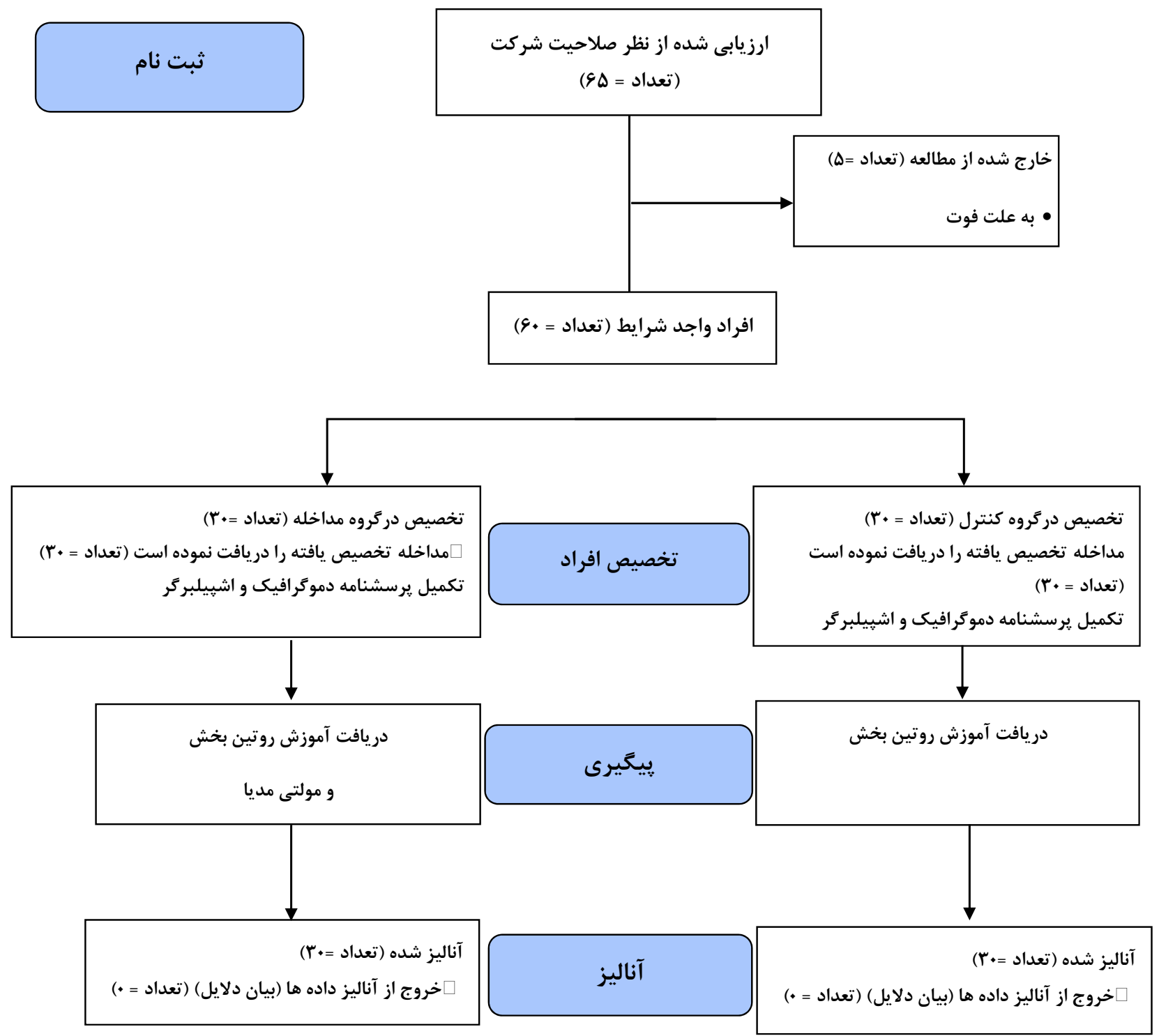
اين طرح در كميته اخلاق دانشعاه علوم يزشكى آجا با كد

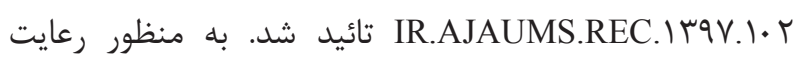
ملاحظات اخلاقى گِس از اخذ رضايت كتبى و اطمينان دادن به بيماران در مورد محفوظ ماندن اطلاعات شخصى، مطالعه انجام

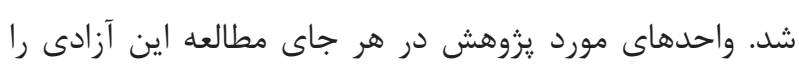

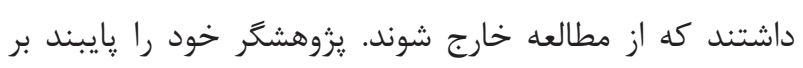
مفاد بيانيه هلسينكى (Helsinki) و اصول كميته اخلاق نشر مارد نيز رعايت گرديد. (Committee of Publication Ethics)

بافتهها قبل از انجام تحليل آمارى، با استفاده از آزمون كولموكروف

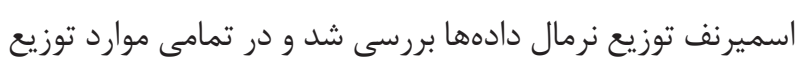

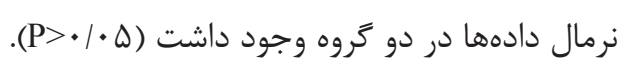

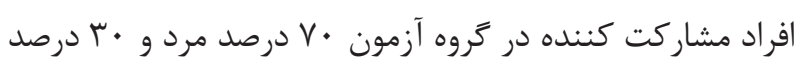

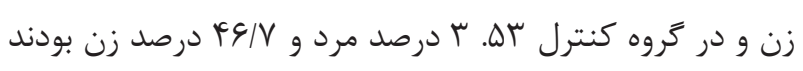

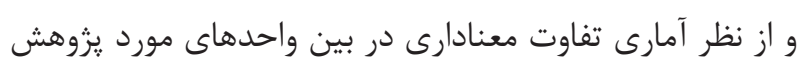

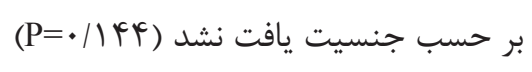

يافتهاى جدول شماره ا نشان مى دهد در دو گروه از نظر تأهل،

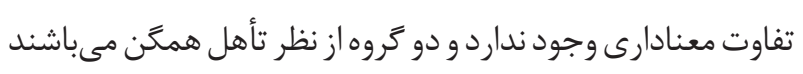

$$
\text { (P>•/・ ه) }
$$

يافتههاى جدول شماره Y نشان مى دهد در دو گروه از نظر وضعيت .

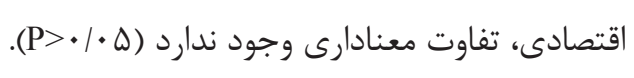

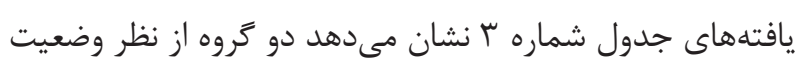
تحصيلات، تفاوت معنادارى را نشان نمى جدهند (ه • P> (P).

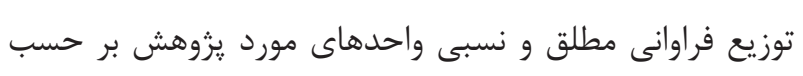

\begin{tabular}{|c|c|c|c|c|}
\hline \multicolumn{4}{|c|}{ تأهل } & \multirow{2}{*}{ توزيع فراوانى مطلق و نسبى مود يثروه } \\
\hline \multicolumn{2}{|c|}{ متأهل } & \multicolumn{2}{|c|}{ 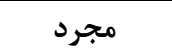 } & \\
\hline درصد & تعداد & درصد & تعداد & \\
\hline $99 / \mathrm{V}$ & $r$. & 每 & 1. & كروه \\
\hline 9. & 11 & r. & $1 \pi$ & كنترل \\
\hline & $X_{r}=$. & $\begin{array}{l}\Delta \Delta F G \\
T \cdot q\end{array}$ & & آزمون دقيق فيشر \\
\hline
\end{tabular}

جدول أ- توزيع فراوانى مطلق و نسبى واحدهاى مورد يزوهش بر حسب

وضعيت تأهل
محدودهى سنى بين | | VD سال، توانايى خواندن و نوشتن يا در

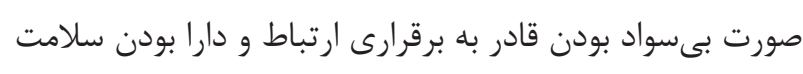

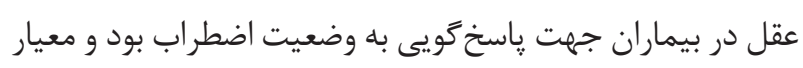

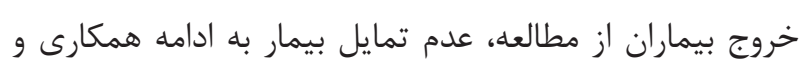
انتقال به مركز درمانى ديخر جهت ادامه درمان مشخص گرَّرديد.

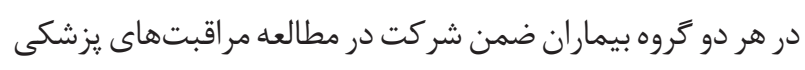
و يرستارى معمول خود را دريافت كردند. در مرحله آموزش ابتدا

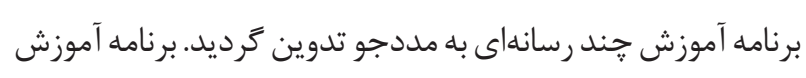

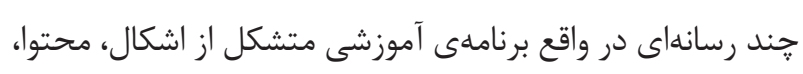
متن، صوت، تصاوير، ويدئو و... جهت انتقال مفاهيم و اطلاعات لازم

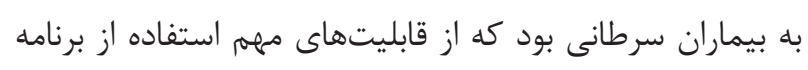

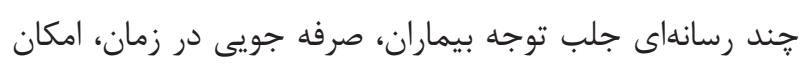
استفاده از آموزشهاى صاحب نظران بدون نياز به حضور فيزيكى نيك

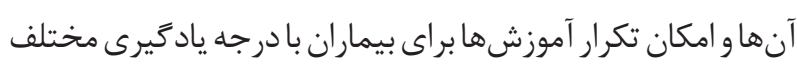
امكان يذير مىشد. جهت اجراى اين مرحله يس از تكميل مطالعات

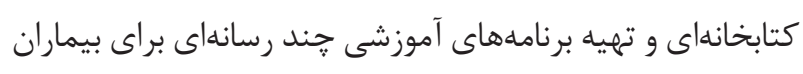

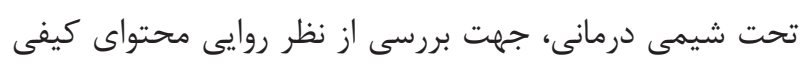

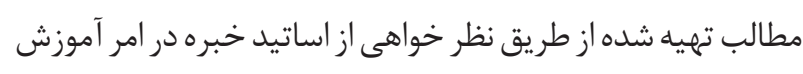

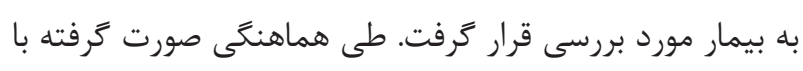

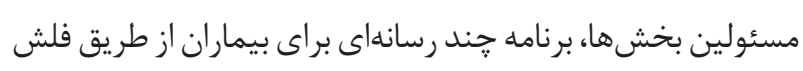

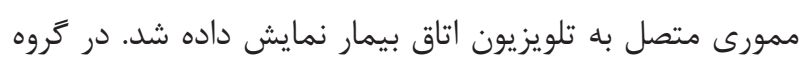
مداخله بيماران حداقل يك بار بسته آموزشى را مشاهده كردند هم:جنين فايل به صورت DVD در اختيار بيماران تروه آزمون قرار

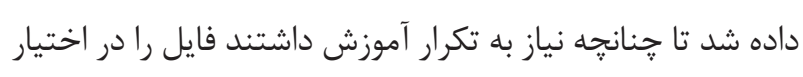

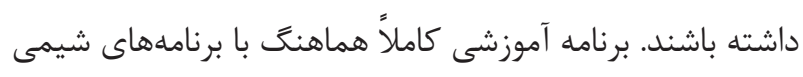

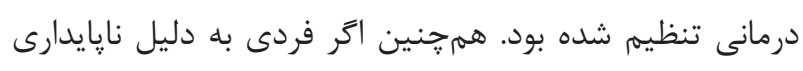

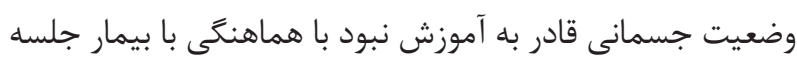

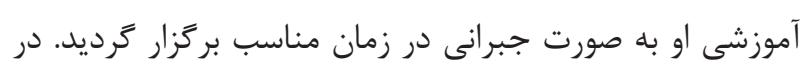

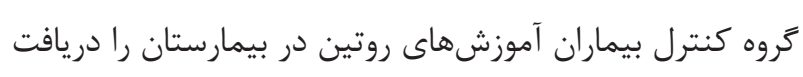

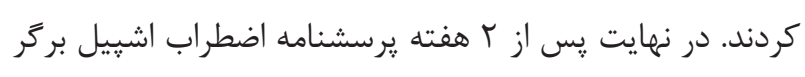
توسط بيماران دو گروه تكميل كرديد.

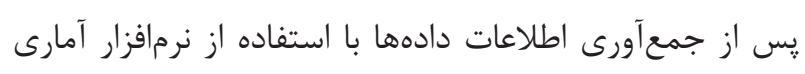

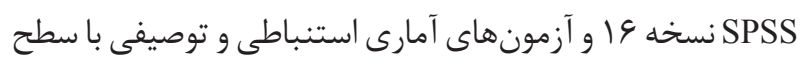

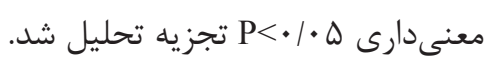


جدول r- توزيع فراوانى مطلق و نسبى واحدهاى مورد يثروهش بر حسب وضعيت اقتصادى

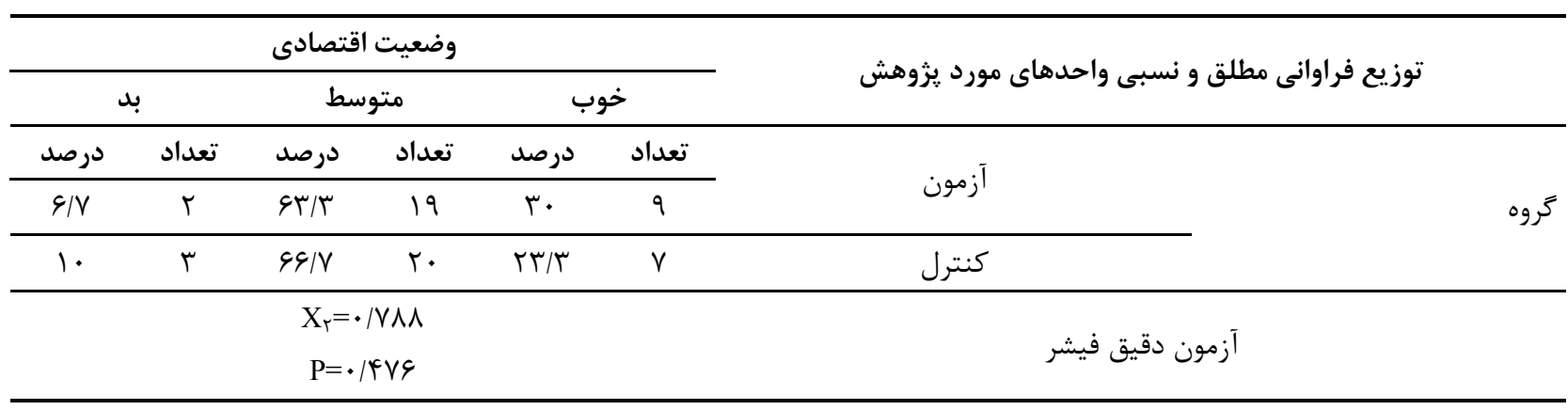

جدول بـ- توزيع فراوانى مطلق و نسبى واحدهاى مورد هُوهش بر حسب وضعيت تحصيلات

\begin{tabular}{|c|c|c|c|c|c|c|c|c|c|c|c|}
\hline \multicolumn{10}{|c|}{ وضعيت تحصيلات } & \multirow{2}{*}{\multicolumn{2}{|c|}{ توزيع فراوانى مطلق و نسبى واحدهاى مورد يزوهش }} \\
\hline \multicolumn{2}{|c|}{ كارشناسى ارشد } & \multicolumn{2}{|c|}{ كارشناسى } & \multicolumn{2}{|c|}{ كاردانى } & \multicolumn{2}{|c|}{ دييلم } & \multicolumn{2}{|c|}{ زير ديّلم } & & \\
\hline درصد & تعداد & درصد & تعداد & درصد & تعداد & درصد & تعداد & درصد & تعداد & & \\
\hline $9 / V$ & $r$ & س & 11 & • & • & س/س" & 1. & $19 / V$ & $\Delta$ & & كروه \\
\hline \multirow[t]{2}{*}{ r/r } & 1 & 1 . & r & $G / V$ & $r$ & $V \cdot$ & rI & $1 \cdot$ & r & كنترل & \\
\hline & & \multicolumn{4}{|c|}{$\mathrm{P}=14 / 9 \wedge \mathrm{V}$} & & & & & & \\
\hline
\end{tabular}

جدول هـ - مقايسه ميانغين نمره اضطراب آشكار بيماران، قبل و بعد از آموزش در دو تروه مورد مطالعه مدائه ميانين

\section{زمان}

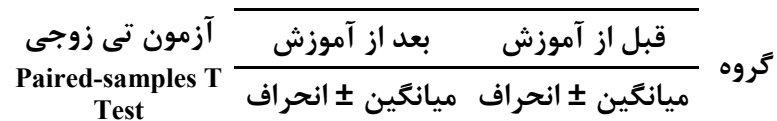

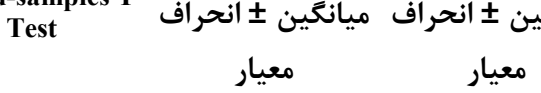

\begin{tabular}{|c|c|c|c|}
\hline $\begin{array}{c}\mathrm{t}=1 / \mathrm{F} \wedge \\
\mathrm{P}=\cdot / / \& q\end{array}$ & $\boldsymbol{F} / \mathcal{F} \cdot \pm \Delta / q \Delta$ & $\mid r / q q \pm q / \cdot \Delta$ & آزمون \\
\hline $\begin{array}{l}\mathrm{t}=\cdot / 4 r \Lambda \\
\mathrm{P}=-1 / 4 \varphi\end{array}$ & $F V / \Delta r \pm 1 \cdot / r r$ & $r \Delta / 1 T \pm 1 \cdot / \varepsilon$. & كنترل \\
\hline
\end{tabular}

متغيرهاى كمى سن، مدت زمان ابتلا به بيمارى و دفعات بسترى در جدول شماره \& Fزارش شده است. يافتههاى جدول نشان مى دهد در دو گروه از نظر سن و مدت زمان ابتلا به بيمارى، تفاوت معنادارى وجود ندارد (ه •/P> ولى از نظر تعداد دفعات بسترى در دو گروه تفاوت معنى دارى به جشم مى خورد (ه) (P) (P) مقايسه ميانگين نمره اضطراب آشكار، قبل و بعد از آموزش در دو گروه در جدول شماره ه و \& قرار گرفته است كه تفاوت آمارى معنادارى در آموزش قبل و بعد دو گروه مشاهده نشد.

جدول F - توزيع فراوانى مطلق و نسبى واحدهاى مورد بزوهش بر حسب متغيرهاى دموكر افيك

\begin{tabular}{|c|c|c|c|c|c|c|c|c|c|}
\hline \multicolumn{9}{|c|}{ متغير هاى كمى } & \multirow{2}{*}{ واحدهاى موزلق و نسبى فراوانى يثروهش } \\
\hline \multicolumn{3}{|c|}{ دفعات بسترى } & \multicolumn{3}{|c|}{ مدت زمان ابتلا به بيمارى } & \multicolumn{3}{|c|}{ سن (سال) } & \\
\hline حداقل & حداكثر & ميانگين و & حداقل & حداكثر & 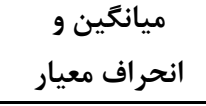 & حداقل & حداكثر & انحراف معيار & \multirow[t]{3}{*}{ آزمون } \\
\hline 1 & 19 & $\Delta \Lambda / \mu \pm \Delta / \cdot \varphi$ & 1 & $i \wedge$ & $V \Psi / I I I T / G r$ & 11 & VI & 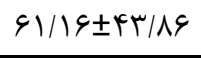 & \\
\hline 1 & $\wedge$ & $V T / I \pm T / I T$ & 1 & $r F$ & $\Lambda F / \Delta \pm q / r q$ & 19 & $V \cdot$ & $|\Delta /| \Delta \pm F \mid / r r$ & \\
\hline \multicolumn{3}{|c|}{$\mathrm{P}=\cdot 1 \cdot 11$} & \multicolumn{3}{|c|}{$\mathrm{P}=\cdot / 19 \Delta$} & \multicolumn{2}{|c|}{$\mathrm{P}=\cdot \mid \Delta T Y$} & $\begin{array}{l}\cdot \mid \Delta T F \\
\cdot|G F|\end{array}$ & آزمون دقيق فيشر \\
\hline
\end{tabular}


جدول 9- مقايسه ميانكَين نمره اضطراب آشكار بيماران، قبل و بعد از مداخله در دو كروه آزمون و كنترل

\begin{tabular}{|c|c|c|c|}
\hline \multirow{3}{*}{$\begin{array}{c}\text { آزمون تى مستقل } \\
\text { Independent } t \text { Test }\end{array}$} & \multicolumn{2}{|c|}{ كروه } & \multirow{3}{*}{ نمره اضطراب } \\
\hline & كنترل & آزمون & \\
\hline & ميانغين & ميانگَين土 انحراف معيار & \\
\hline $\begin{array}{l}\mathrm{t}=-\cdot / \Delta T H \\
\mathrm{P}=\cdot \mid 9 \cdot \mu\end{array}$ & $F \Delta / 1 T \pm 1 \cdot / 9$. & $\mid q / q \varepsilon \pm \varepsilon / \cdot \Delta$ & اضطراب قبل از مداخله \\
\hline $\begin{array}{l}\mathrm{t}=-1,9 . \\
\mathrm{P}=\cdot 1 \cdot 9 \mathrm{r}\end{array}$ & $F V / \Delta r \pm 1 \cdot / r r$ & $\mathcal{E} / \mathcal{F} \cdot \pm \Delta / 9 \Delta$ & اضطراب بعد از مداخله \\
\hline
\end{tabular}

و خود مراقبتى بيماران با يرسشنامه مورد بررسى قرار كرفت. ميانخين سنى كروه آزمون

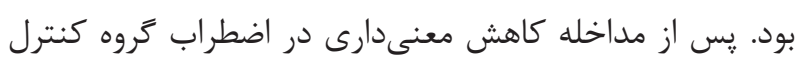

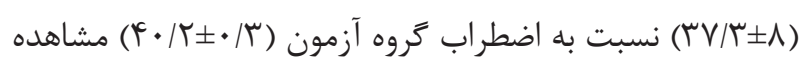

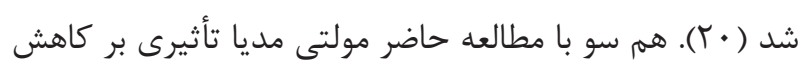

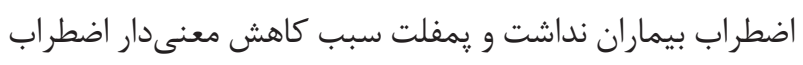

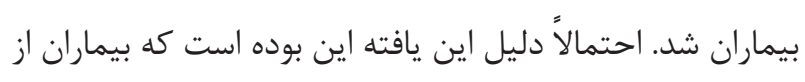

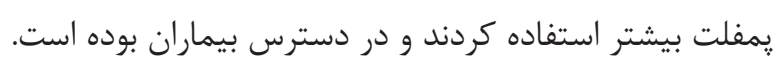
در مطالعه هاريسون (Harrison) و همكاران در كروه آزمون از فيلم آموزشى و گروه كنترل از ليفلت براى كاهش اضطراب بيماران

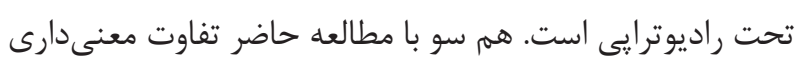

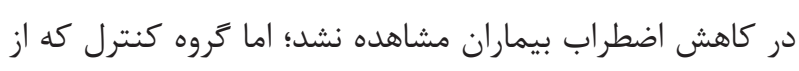

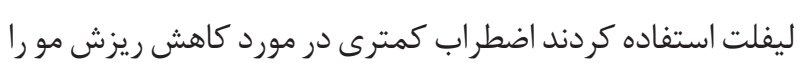
كزارش كردند. مطالعه هاريسون نشان داد كه دستيابى به اطلاعات عمومى با استفاده از ليفلت در مقايسه با ابزارهاى كاملاً ديدارى و و دئل

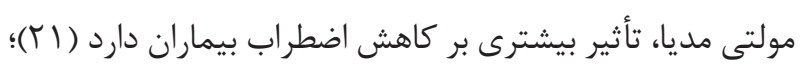

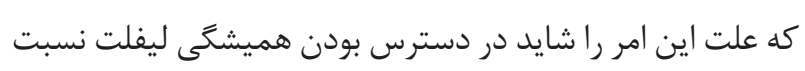
به مولتى مديا براى بيمار و سهولت مراجعه وى دانست. نتايج

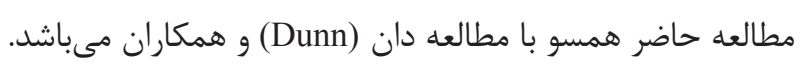

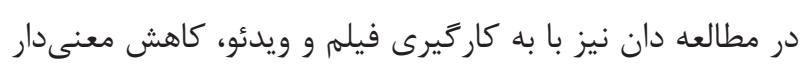

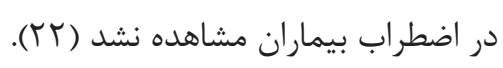

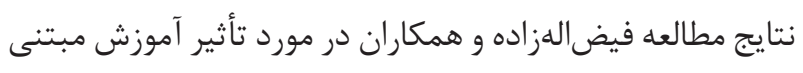
بر نرمافزار حند رسانهاى و شيوه سنتى بر كيفيت زندكى بيماران

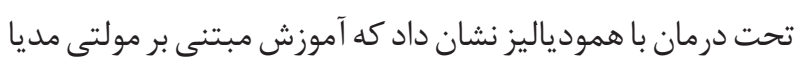

"همودياليز و مراقبتهاى لازم" نيز همانند شيوه سنتى موجب بهبود كيفيت زندگى در بيماران مىشود كه علت آن مى تواند تأثير

\section{بحث و نتيجه كيرى}

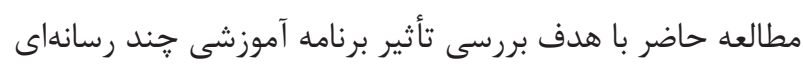

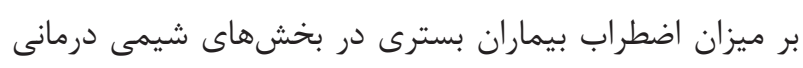

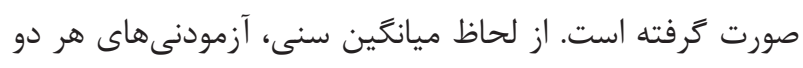

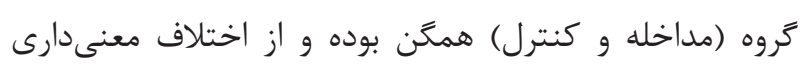

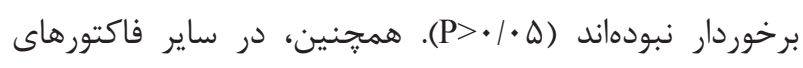
جمعيت شناختى از قبيل جنس، وضعيت تأهل، وضعيت

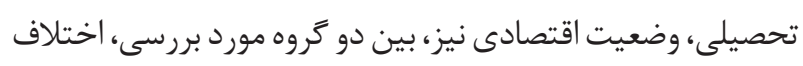

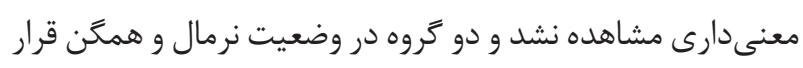

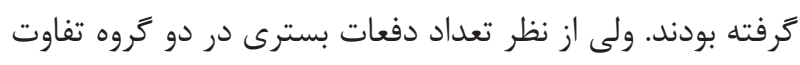

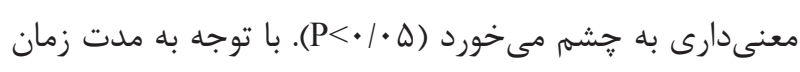

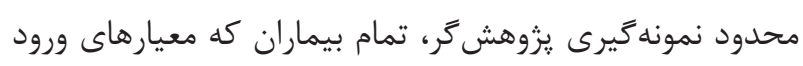

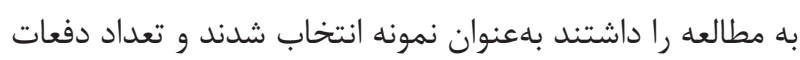
بسترى به عنوان معيار ورود در نظر گرفته نشده بود. يافتههاى مطالعه نشان داد، بين ميانخين نمره اضطراب آشكار قبل

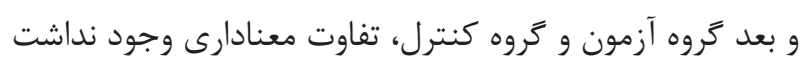

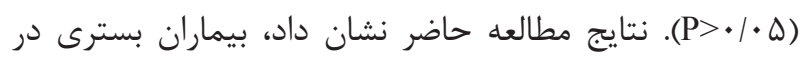

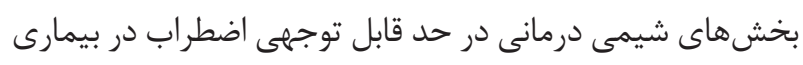

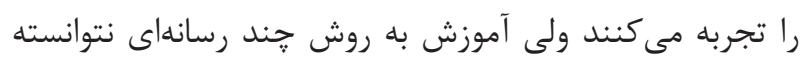

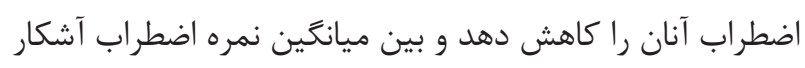

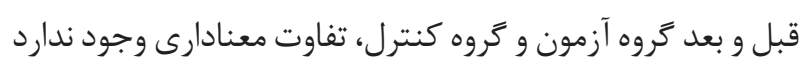

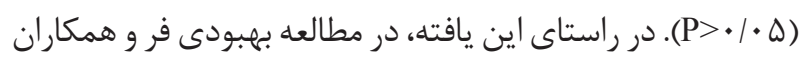

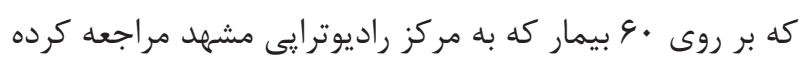

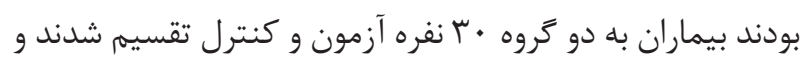
در گروه آزمون يك جلسه تحت آموزش از طريق مولتى مديا قرار

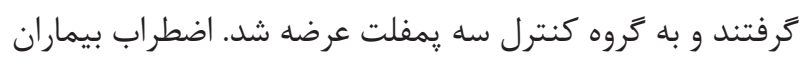


همجنين نتايج مطالعات جعفرى يورزارع با عنوان بررسى تأثير

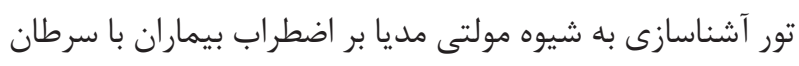

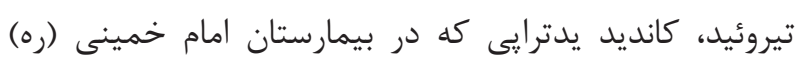

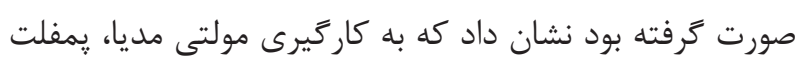

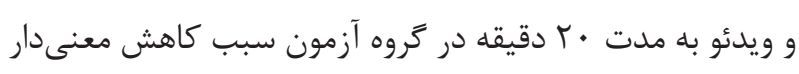

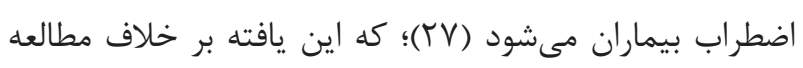

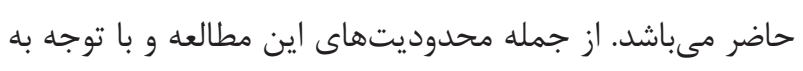

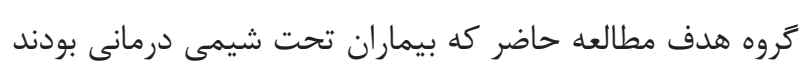
به نظر مىرسد كه شرايط و وخامت حال بيماران نيز به عنوان

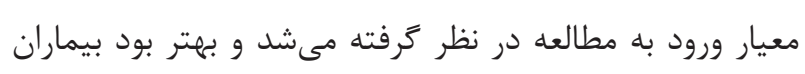
در جلسات ابتدايى كموترايى وارد مطالعه مىشدند. آموزش به به ديه

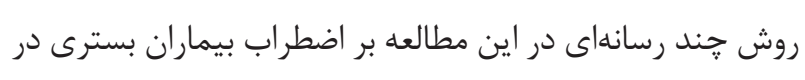

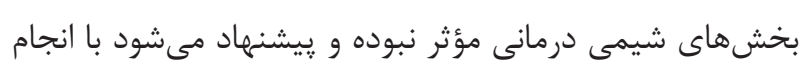

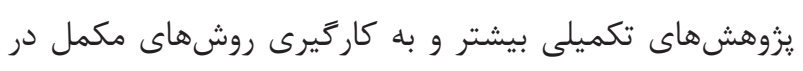
كنار اين روش تأثيرات آنها بررسى كردد.

\section{تشكر و قدردانى}

اين مقاله بركرفته از پايان نامه كارشناسى ارشد رشتى رشته روان

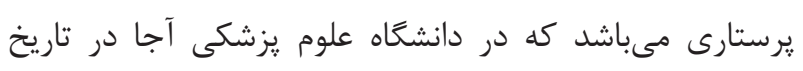

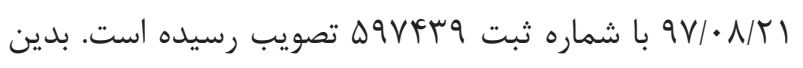

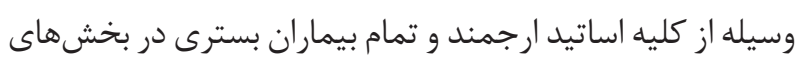
شيمى درمانى كه ما را در جهت اجراى اين مطالعه يارى نمودند، كمال تشكر و قدردانى را داريم.

تضاد منافع بين نويسند نداشته و مقاله با همكارى و هماهنكى تمامى نويسند كان نكاشته شده است.

\section{References}

1- Rouhollahi MR, Mohagheghi MA, Mohammadrezai N, Ghiasvand R, Ghanbari Motlagh A, Harirchi I, et al. Situation analysis of the National Comprehensive Cancer Control Program (2013) in the I. R. of Iran; assessment and recommendations based on the IAEA imPACT mission. Arch Iran Med. 2014;17(4):222-31. DOI:
ويزگى هاى جند رسانهاى نرم افزار "همودياليز و مراقبت هاى لازم" بر بهبود يادگيرى و تغييرات مثبت رفتارى در بيماران باشد (سب). يافتههاى مطالعه فيض زاده هم سو با يافتههاى مطالعه حاضر

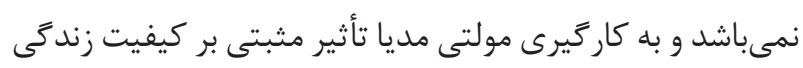

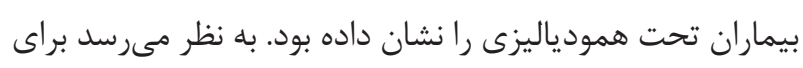

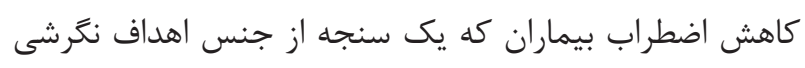
مىباشد لازم است از جلسات بيشتر آموزشى و جند روش تدريس در كنار هم استفاده نمود. بر خلاف نتايج مطالعه حاضر، به كارگيرى ديسك فشرده براى آموزش ريشخيرى از سقوط سالمندان در مطالعه هيل (Hill) و همكاران امتياز معنى دارى را كسب كرد (TY) (T). در مطالعه صالح مقدم و همكاران باعنوان بررسى تأثير فيلم آموزشى بر اضطراب قبل از عمل بيماران تحت عمل جراحى قلب باز بدون يمٍ، تفاوت

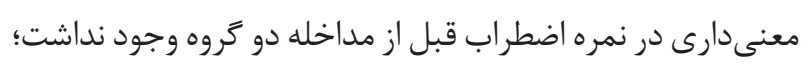
كه اين قسمت يافته مطالعه صالح مقدم هم سو با مطالعه حاضر معرد مىباشد اما بعد از مداخله تفاوت معنىدارى در كاهش اضطراب

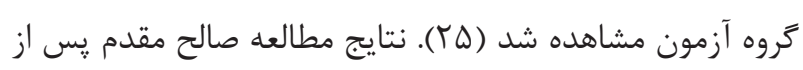
مداخله تائيد كننده يافته مطالعه حاضر نمىباشد. يافته مطالعه ديخرى كه خلاف يافته مطالعه حاضر بود مطالعه

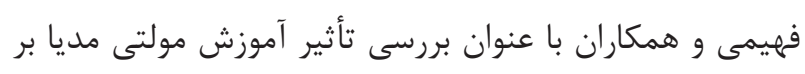
اضطراب قبل و بعد از جراحى باى پِ عروق قلبى بود كه در دو

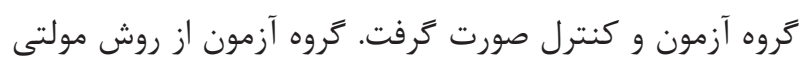
مديا و زروه كنترل روش روتين را بكار گرفتند. آناليز مطالعه نشان داد كه هر دو گروه در متغيرهاى دموگرافيك همگن بودند روند و در سه مرحله بررسى ميزان اضطراب بيماران تفاوت معنى دارى

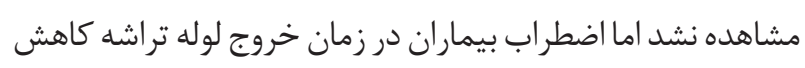

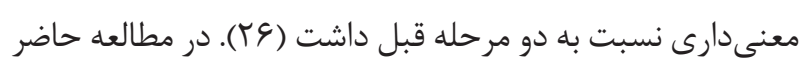
اضطراب بيماران يس از مداخله تفاوت معنى دارى را نشان نداد.

014174/AIM.003 PMID: 24724597

2- Radmard AR. Five common cancers in Iran. Archives of Iranian medicine. 2010;13(2):143.

3- Chen W, Zheng R, Zhang S, Zhao P, Li G, Wu L, et al. Report of incidence and mortality in China cancer registries, 2009. Chin 
J Cancer Res. 2013;25(1):10-21. DOI: 10.3978/j.issn.10009604.2012.12.04 PMID: 23372337

4- Ferlay J, Steliarova-Foucher E, Lortet-Tieulent J, Rosso S, Coebergh JW, Comber H, et al. Cancer incidence and mortality patterns in Europe: estimates for 40 countries in 2012. Eur J Cancer. 2013;49(6):1374-403. DOI: 10.1016/j.ejca.2012.12.027 PMID: 23485231

5- Abachizadeh K, Keramatinia A. Anticipating cancer rates of Iran in 2025. CHJ. 2016;3(1):66-73.

6- Vanaki Z, Matourypour P, Gholami R, Zare Z, Mehrzad V, Dehghan M. Therapeutic touch for nausea in breast cancer patients receiving chemotherapy: Composing a treatment. Complement Ther Clin Pract. 2016;22:64-8. DOI: 10.1016/j.ctcp.2015.12.004 PMID: 26850808

7- Al Sadat Alavi N, Aqsa Fard Z. Metastasis of breast cancer to the thyroid gland a case report and review of literature. IJBD. 2009;2(1):52-6.

8- Shun SC, Yeh KH, Liang JT, Huang J, Chen SC, Lin BR, et al. Unmet supportive care needs of patients with colorectal cancer: significant differences by type D personality. Oncol Nurs Forum. 2014;41(1):E3-11. DOI: 10.1188/14.ONF.E3-E11 PMID: 24368251

9- Taoka R, Matsunaga H, Kubo T, Suzuki T, Yamamoto S. Impact of trait anxiety on psychological well-being in men with prostate cancer. Int Braz J Urol. 2014;40(5):620-6. DOI: 10.1590/S16775538.IBJU.2014.05.06 PMID: 25498273

10- Traeger L, Greer JA, Fernandez-Robles C, Temel JS, Pirl WF. Evidence-based treatment of anxiety in patients with cancer. J Clin Oncol. 2012;30(11):1197-205. DOI: 10.1200/JCO.2011.39.5632 PMID: 22412135

11- Asadi A, Zareei F, Nasiri A, Moraveji S, Kaikhani R, Tehrani H. Digital media and health. Tehran: Asare sobhan; 2011.

12- Keulers BJ, Welters CF, Spauwen PH, Houpt P. Can face-toface patient education be replaced by computer-based patient education? A randomised trial. Patient Educ Couns. 2007;67(12):176-82. DOI: 10.1016/j.pec.2007.03.012 PMID: 17448621

13- Casazza K, Ciccazzo M. The method of delivery of nutrition and physical activity information may play a role in eliciting behavior changes in adolescents. Eat Behav. 2007;8(1):73-82. DOI: 10.1016/j.eatbeh.2006.01.007 PMID: 17174854

14- Mohammady M, Memari A, Shaban M, Mehran A, Yavari P, Salari Far M. Comparing computer-assisted vs. face to face education on dietary adherence among patients with myocardial infarction. Journal of hayat. 2011;16(3):77-85.

15- Varaei S, Mamashli L, Ghiyasvandian S, Bahrani N. The Effect of Multimedia Education Program on Knowledge and Practice of Nurses about Safe Injection. Iran J Nursing. 2016;29(103):68-77. DOI: $10.29252 /$ ijn.29.103.68

16- Campbell MK, Carbone E, Honess-Morreale L, HeislerMackinnon J, Demissie S, Farrell D. Randomized trial of a tailored nutrition education CD-ROM program for women receiving food assistance. J Nutr Educ Behav. 2004;36(2):58-66. DOI: 10.1016/ s1499-4046(06)60134-6 PMID: 15068753

17- Saffari M, Shojaeezadeh D, Mahmoodi M, Hosseini S. A comparison between two health education methods on diet: lecture versus videotape. Health Monitor Journal of the Iranian Institute for Health Sciences Research. 2011;10(1):63-71.

18- Mohammad Aliha Z, Ghani Dehkordi F, Ganji T, Hosseini F. The effect of education on patient's anxiety after myocardial infarction. Mandish; 2012. p. 65-75.

19- Aghakhani N, Khademvatan K, Habibzadeh H, Jasemi M, Eghtedar S, Parkha M, et al. The effect of education on anxiety and depression in patients with myocardial infarction in selected hospitals, Iran. J Urmia Univ Med Sci. 2012;23(2):105-14.

20- Behboudifar A, Heshmati Nabavi F, Assarroudi A. Anxiety and Self-care Behavior in Patients Undergoing Head and Neck Radiotherapy: Effect of Print and Multimedia Health Materials. Evidence Based Care. 2018;8(2):18-27.

21- Harrison R, Dey P, Slevin NJ, Eardley A, Gibbs A, Cowan R, et al. Randomized controlled trial to assess the effectiveness of a videotape about radiotherapy. Br J Cancer. 2001;84(1):8-10. DOI: 10.1054/bjoc.2000.1536 PMID: 11139305

22- Dunn J, Steginga SK, Rose P, Scott J, Allison R. Evaluating patient education materials about radiation therapy. Patient Educ Couns. 2004;52(3):325-32. DOI: 10.1016/S0738-3991(03)001083 PMID: 14998603

23- Feizalahzadeh H, Zagheri Tafreshi M, Moghaddasi H, Ashghali Farahani M, Zareh Z, Khalilzadeh M. Effectiveness of multimedia based on education and traditional methods on life quality of hemodialysis patients. Journal of Holistic Nursing And Midwifery. 2016;26(2):69-78.

24- Hill AM, McPhail S, Hoffmann T, Hill K, Oliver D, Beer C, et al. A randomized trial comparing digital video disc with written delivery of falls prevention education for older patients in hospital. J Am Geriatr Soc. 2009;57(8):1458-63. DOI: 10.1111/j.15325415.2009.02346.x PMID: 19515102

25- SalehMoghaddam A, Mazloum S, Zoka A. The effect of educational videos on preoperation anxiety among patients before undergoing open heart surgerywithout pump. The J Urmia Nurs Midwifery Fac. 2016;14(7):648-57.

26- Fahimi K. Investigation of the Effect of Multimedia Education on Anxiety Before and After Surgery in Patients Undergoing Coronary Artery Bypass Graft Surgery. Scientific Journal of Hamadan Nursing \& Midwifery Faculty. 2018;26(3):144-37. DOI: 10.30699/sjhnmf.26.3.144

27- Jafari Pourzare SL, Khankeh HR, Nourozi Tabrizi K, Biglarian A, Farzaneh Far S. Effect of Multimedia Orientation Tour on Anxiety of Patients with Thyroid Cancer of Candidate Iodine Therapy. Iranian J Rehabilitation Research. 2018;4(4):36-43. 